\title{
Uf
}

Volume: 18 Issue: 4 Year: 2021

\section{The analysis of the perception of \\ prospective music teachers on musical dictation through methaphors}

\author{
Müzik öğretmeni adaylarının \\ müziksel dikte yazmaya ilişkin \\ algilarının metaforlar aracılığıyla \\ incelenmesi
}

\section{Esin Uçal Canakay ${ }^{1}$}

\section{Özet}

Müziksel işitme eğitimi, müzik öğretmeni adaylarının öğrenim yaşantılarında önem derecesine göre ilk sıralarda yer alabilecek bir alandır. Çünkü müziksel işitme, müzik eğitiminin diğer tüm alanlanında başarıyı etkileyebilecek bir yere sahiptir. Mesleki eğitimlerinde aldıklanı birçok derse etki etmesi ve müziksel gelişimlerini doğrudan etkilemesi sebebiyle müzik öğretmeni adaylarının müziksel işitme becerilerinin geliştirilmesinde büyük yer tutan dikte yazma çalışmalarını nasıl değerlendirdiklerinin belirlenmesi önem arz etmektedir.

Eğitim bilimleri disiplini çerçevesinde eğitimin çeşitli kademelerinde bireylerin çeşitli kavramlara yönelik algilarının metaforlar aracillğıyla incelendiği çalışmalara rastlanmaktadır. Gerçekleştirilen literatür taramasında müzik eğitimi alanında metaforların veri toplama aracı olarak kullanıldığ1 araştırmaların sayısının, eğitimin diğer alanlarına göre daha az olduğu görülmüştür. Bu sebeple bu araştırmada müzik öğretmeni adaylarının müziksel dikte yazmaya yönelik alg1larının belirlenmesinde metaforlardan faydalanilması uygun görülmüştür.

Bu araştırmanın çalışma grubunu 2018-2019 ögrretim yilında Dokuz Eylül Üniversitesi Buca Eğitim Fakültesi Müzik Eğitimi Anabilim Dalı'nda öğrenim gören 93 öğrenci

\footnotetext{
1 Asst. Prof. Dr., Dokuz Eylul University, Buca Faculty of Education, Department of Music Education, esin.canakay@deu.edu.tr (D) Orcid ID:-0000-0003-2476-8287
} 
Uçal Canakay, E. (2021). Müzik öğretmeni adaylarının müziksel dikte yazmaya ilişkin algılarının metaforlar aracıllı̆ıyla incelenmesi. Journal of Human Sciences, 18(4), 665-680. doi:10.14687/jhs.v18i4.6260

analysis. In the content analysis stage, 11 data excluded.

Finding results shows that 82 prospective music teachers have produced 70 metaphors on dictation writing. Prospective music teachers produced metaphors on dictation writing categorized in 9, which are (19,51\%) giving happiness, (19,51\%) needs attention, (13,41\%) analysis, (9,76\%) caused mixed emotions, (8,54\%) concreting, (8,54\%) difficulty, (8,54\%) needs effort, $(7,32 \%)$ developing, and (4,88\%) troublesome. It is found out that prospective teachers used metaphors like puzzle / crossword / puzzle solving $(\mathrm{f}=12)$, playing strategy game on computer $(\mathrm{f}=4)$ and solving math problems $(\mathrm{f}=4)$.

Keywords: Musical hearing, musical dictation, prospective music teacher, metaphor.

(Extended English summary is at the end of this document) oluşturmaktadır. Araştırmanın verileri "dikte yazmak ....... gibidir. Çünkü ......" şeklinde boşluklar bırakılmış bir form ile toplanmıştır. Toplanan verilerin çözümlenmesinde içerik analizinden faydalanılmışırı. Analiz aşamasında 11 veri kapsam dışında bırakılmıştır.

Araştırma sonuçları 82 müzik öğretmeni adayının dikte yazmaya ilişkin toplam 70 metafor ürettiğini göstermektedir. Müzik öğretmeni adaylarının dikte yazmaya ilişkin ürettikleri metaforlar mutluluk veren $(\% 19,51)$, dikekat gerektiren (\%19,51), çözümleme (\%13,41), karışı duygulara yol açan (\%9,76), somutlastrma $(\% 8,54)$, zorluk $(\% 8,54)$, emek ve çaba isteyen $(\% 8,54)$, gelisim sağlayan $(\% 7,32)$, sılkintı veren $(\% 4,88)$ olmak üzere toplam 9 kategoride toplanmıştır. Öğretmen adaylarının en sik bilmece/bulmaca/bulmaca çözmek $(\mathrm{f}=12)$, bilgisayarda strateji oyunu oynamak $(\mathrm{f}=4)$ ve matematik problemi çözmek $(\mathrm{f}=4)$ metaforlarını kullandıkları görülmektedir.

Anahtar Kelimeler: Müziksel işitme, müziksel dikte, müzik öğretmeni adayı, metafor.

\section{GİRİŞ}

Müziksel işitme eğitimi, müzik öğretmeni adaylarının öğrenim yaşantılarında önem derecesine göre ilk sıralarda yer alabilecek bir alandır. Çünkü müziksel işitme, müzik eğitiminin diğer tüm alanlarında başarıyı etkileyebilecek bir yere sahiptir. İşitilen bir sesi, akoru, ritmik yapıyı, melodiyi algılayabilmek, anlamlandırabilmek ve nota yazısına dökmek için, doğaçlama ve müziksel yaratma çalışmaları için ve ayrıca enstrüman çalma ve şarkı söyleme çalışmalarında etkili bir müzikal yorumlamanın gerçekleşebilmesi için işitsel yetinin iyi düzeyde olmasına gereksinim vardır.

İşitsel beceriler, birçok farklı müziksel beceriyi bir şemsiye altında toplayan geniş bir kavramdır. Bu beceriler; müziği duyma ve anlama, deşifre söyleme, dikte yazma (melodik, armonik, ritmik), yanlışı bulma ve işitsel form analizidir (Powell, 2013, s. 1). Müziksel işitme eğitiminde; tonal alg1 ve tonal hakimiyet hem teorik hem de edimsel yönleriyle ele alınmaktadır. Müziksel işitme alanının duyuş, solfej okuma, deşifre okuma, dikte yazma, armonik ve biçimsel analiz yapma etkinliklerinin her birinde ton bilgisi ve tonal duygudan yola çıkılmaktadır. Tonal alg1 ve hakimiyetin gelişimiyle birlikte tek sesli diktelerden iki sesli ve üç sesli ezgi diktelerine, üç sesli ve dört sesli akor diktelerine rahatlıkla geçiş yapılabilmektedir. Mesleki müzik eğitimi veren kurumlarda yatay ve dikey çoksesliliği anlama ve duyma ile ilgili hedeflerin gerçekleştirilmesinde, bu çalısmalar büyük oranda katkı sağlamaktadır.

Üniversitelerin mesleki müzik eğitimi veren lisans programlarında müziksel işitme çalışmalarının yer aldığı dersler, farklı isimlerle yer almaktadır. Dersin isimleri farklılık gösterse de, ders içerikleri benzer çalısmaları kapsamaktadır. Dikte yazma çalışmaları, müziksel işitme dersleri içinde en geniş zaman ayrılan çalışmalardan biridir. Müziksel dikte yazma çalışmalarında, genellikle öğrenciler kendilerine çalınan melodik, ritmik ya da armonik bir parçayı küçük bölümlere ayrılmış olarak (örneğin iki ölçü uzunluğunda) dinlerler. Bazı öğrenciler dinlerken aynı zamanda dinledikleri bölümü notaya alabilmektedirler. Ancak bazı öğrenciler ise dinledikleri bölümü kısa süreli belleğe alır, 
Uçal Canakay, E. (2021). Müzik öğretmeni adaylarının müziksel dikte yazmaya ilişkin algılarının metaforlar aracıllı̆ıyla incelenmesi. Journal of Human Sciences, 18(4), 665-680. doi:10.14687/jhs.v18i4.6260

tonal olarak analizini yapar, ölçü sistemine göre ritmik yapıyı zihninde şekillendirir ve hemen ardından notasyona dönüștürür. Nota ve sus değerleri, ölçü sistemleri, tonalite, ritmik yapılar, müzikal cümleler, kadanslar, akor bilgisi gibi öğrenilen tüm teorik bilgiler, çalınan dikte parçasının notaya alınması sırasında can bulmuş olur. Öğrenciler, dikte yazarken tüm işitsel becerilerini en üst düzeyde ortaya koymak zorundadırlar. Ancak yorgun olmak, uykusuz olmak, hasta olmak, ders saatinin günün geç saatlerinde olması, çevreden gelen seslerin rahatsız etmesi, anlık bir dikkat dağınıklığı, sınıf ortamındaki gerginlik ve bunlar gibi daha birçok sebep öğrencinin dikte yazma performansını düşürebilmektedir. Bu nedenle öğrenciler teorik bilgisine güveniyor ve iyi bir işitsel algiya sahip olduğuna inanıyor olsa bile dikte yazarken kaygı duyabilmektedirler. Dikte parçasının çalınması sırasında oluşabilecek herhangi bir olumsuz çevresel etken, öğrencilerin diktenin sonuna kadar başarnyla ilerlemesine engel olabilmektedir. Bu nedenle öğrenciler dikte yazmaya başlarken bile başaramayacaklarına dair endişe taşıyabilmektedir. Arka arkaya birkaç kez yaşanmış olumsuz deneyim ise öğrencilerde dikte yazma korkusuna neden olabilmektedir. Bu durum onları başarısızlı̆ga itecek önemli bir duyuşsal faktördür. Müzik Eğitimi Anabilim Dalları'nda öğrencilerin genellikle benzer duyguları taşıdığı bilinmektedir. Mesleki eğitimlerinde aldıkları birçok derse etki etmesi ve müziksel gelişimlerini doğrudan etkilemesi sebebiyle müzik öğretmeni adaylarının müziksel işitme becerilerinin geliştirilmesinde büyük yer tutan dikte yazma çalışmalarını nasıl değerlendirdiklerinin belirlenmesi önem arz etmektedir.

Son yıllarda öğrenci, öğretmen veya öğretmen adaylarının duygu, düşünce veya görüşlerine başvurulan eğitim araştırmalarında metaforlardan yararlanıldığı görülmektedir. Metaforlar güçlü ifade aracıdır. Ayrıca öğrenme ortamı içinde de metaforik düşünce ve metaforik anlatıma sıklıkla yer verilmektedir. Saban (2008, s. 490), metaforların öğretmen adaylarının eğitiminde belli olgulara ilişkin sahip oldukları zihinsel imgeleri açığa çıkarmada, anlamada ve belki de onları değiştirmede güçlü bir "pedagojik araç" olarak kullanabileceğini belirtmiştir. Öğretmen adaylarının zihinlerinde şemaları oluşturabilmeleri ve gerektiğinde bu şemaları yeniden yapılandırmaları gerektiğinde metaforlardan faydalanilabilmektedir.

Lakoff (1993, s. 1-2) kavramsal metafor kuraminda, farklı kavramsal alanlar arasinda deneyimlerden yola çıkarak eşleme yapmaktan söz etmektedir. Anlatılmak istenen hedef kavramın açıklanması için, başka bir zihinsel alanda yer alan kavram kaynak olarak kullanılır, bu kaynak kavramdan yola çıkarak iki alan arasında bir eşleme yapılır.

Metafor; bir kavramı, kelimeyi, terimi, olguyu daha güzel ve iyi anlatmak amaciyla, başka bir anlamda olan bir sözcükle, ilgi kurularak benzetme yoluyla kullanılmasıdır (Aydın, 2004, s.10).

Metaforlar günlük konuşmalardan edebi anlatımlara, siyasi demeçlerden akademik yayınlara hayatın her aşamasında sözel iletişimin bir parçası olarak kullanılmaktadırlar. Benzetme, veya çağrışımlar yapma yoluyla soyut, karmaşık, anlatılması güç olan olgu veya kavramların daha rahat anlaşılır hale gelmesine yardımcı olmaktadırlar. Botha (2009, s. 431), metaforların, edebiyatta olduğu kadar eğitimde de estetik ve pedagojik açıdan önemli rol oynadığını ifade etmiştir. Arslan ve Bayrakçı'ya göre öğrencilerin zor kavram ve terimleri anlamalarında, öğrenilen bilgilerin akılda daha uzun süre kalmasını ve daha kolay hatırlanmasını sağlamakta metaforlar son derece yararlı olmaktadır (2006, s. 106).

Öğrenci görüşlerinin alındığı eğitim araştırmalarında metaforların bir araç kullanılması kolaylık sağlamaktadır. Çünkü öğrenciler düşüncelerini metaforlar yoluyla daha rahat hissederek ifade edebilirler. Günlük konuşma dilinde de çokça kullanılan metaforlar, onların anlatmak istedikleri şeyi zorlanmadan aktarabilmelerine yardımcı olmaktadır.

Patton'a göre (2018, s. 505) metaforlar, bulguları iletmekte güçlü ve zekice bir yoldur. Çünkü güçlü bir metafor ile çok fazla anlam ifade edilebilmektedir. Üstelik metafor geliştirmek ve kullanmak hem analizi yapan kişi hem de okuyucu için eğlenceli olabilir. Bu nedenledir ki son yıllarda ülkemizde de akademik çalışmalar içinde birçok konu metaforların kullanılmasıyla ele alınmaktadır (Saban, 2002; Bozpolat, 2016; Kılcan, Akbaba ve Gülbudak, 2017; Şahin-Kalyon ve Aksoy, 2017; Büyükalan ve Yaylac1, 2018; Şahin, 2018; Özevin ve Kaya, 2019; Ulusoy, 2020; Demirbilek ve Atila, 2021; Saylik, Saylık ve Sağlam, 2021). 
Uçal Canakay, E. (2021). Müzik öğretmeni adaylarının müziksel dikte yazmaya ilişkin algılarının metaforlar aracıllı̆ıyla incelenmesi. Journal of Human Sciences, 18(4), 665-680. doi:10.14687/jhs.v18i4.6260

Eğitim bilimleri disiplini çerçevesinde eğitimin çeşitli kademelerinde bireylerin çeşitli kavramlara yönelik algılarının metaforlar aracıllọ̆ıla incelendiği çalışmalara rastlanmaktadır. Bu çalışmalar içerisinde müzik eğitimi araştırmaları da dikkat çekmektedir. Düzgören ve Gerekten (2017), Anadolu Lisesi öğrencilerinin 'Müzik Dersi' kavramına ilişkin algılarını metaforlar aracilı̆ı ile incelemiş ve öğrencilerin müzik dersine ilişkin 'aşk', 'hayat', 'nefes' gibi olumlu duygulara işaret eden metaforlar geliştirdikleri sonucunu paylaşmışlardır. Bir başka çalışmada Anadolu Güzel Sanatlar Lisesi müzik öğrencilerinin 'müzik' kavramına ilişkin algılarının belirlenmesi için metaforlar kullanılmışır (Babacan, 2014). Bu çalısmada öğrencilerin 'müzik' kavramına ilişkin olarak 9 kategoride incelenen çok çeşitli metaforlar ürettikleri görülmektedir. Gerçekleştirilen literatür taramasında müzik eğitimi alanında metaforların veri toplama aracı olarak kullanıldığı araştırmaların sayısının, eğitimin diğer alanlarına göre daha az olduğu görülmüştür. Bu sebeple bu araştırmada müzik öğretmeni adaylarının müziksel dikte yazmaya yönelik algılarının belirlenmesinde metaforlardan faydalanılması uygun görülmüştür.

Bu çalısmanın amacı, müzik öğretmeni adaylarının müziksel dikte yazmaya ilişkin algılarını metaforlar aracıllğıyla belirlemektir. Bu amaç doğrultusunda aşağıdaki sorulara yanıt aranmıştır:

1. Müzik öğretmeni adayları müziksel dikte yazamaya ilişkin algılarını hangi metaforlarla ifade etmişlerdir?

2. Müzik öğretmeni adaylarının müziksel dikte yazamaya ilişkin ürettikleri metaforlar hangi kavramsal kategoriler altında toplanmaktadır?

\section{YÖNTEM}

Müzik öğretmeni adaylarının müziksel dikte yazmaya ilişkin algılarının incelenmesi amacıyla yapılan bu çalışmada, nitel araştırma yöntemi benimsenmiştir. Nitel araştırma yöntemlerine dayalı olarak yürütülen bu araştırmanın çalışma grubu, araştırma verilerinin toplanması ve verilerin analizi yöntem bölümünde anlatılmaktadır.

\section{Çalışma Grubu}

Bu araştırmanın çalışma grubunu 2018-2019 öğretim yllında Dokuz Eylül Üniversitesi Buca Eğitim Fakültesi Güzel Sanatlar Eğitimi Bölümü Müzik Eğitimi Anabilim Dalı'nda Lisans 1, 2, 3 ve 4. sınıflarında öğrenim gören öğrenciler oluşturmaktadır. Öğrenci gruplarıyla bir araya gelindiğinde araştırmacı tarafından bu bilimsel çalışmaya katılmanın gönüllülük esasına dayalı olduğu, katılımcı isimlerinin saklı tutulacağı ve araştırma verilerinin bilimsel amaç dışında kullanılmayacağı açı bir dille ifade edilmiştir. Böylece bu çalışma, gönüllü olan 93 öğretmen adayının katılımı ile gerçekleşmiştir. Araştırmanın çalışma grubunu oluşturan müzik öğretmeni adaylarının cinsiyet ve sınıf düzeylerine göre dağılımları Tablo 1'de verilmiştir.

Tablo 1. Müzik öğretmeni adaylarının cinsiyet ve sınıf düzeyine göre dağıllımı

\begin{tabular}{|l|c|c|}
\hline Cinsiyet & $\mathbf{n}$ & $\mathbf{\%}$ \\
\hline Kadın & 68 & 73,1 \\
Erkek & 25 & 26,9 \\
\hline TOPLAM & 93 & 100 \\
\hline Sinıf düzeyi & & \\
\hline 1. sinıf & 23 & 24,8 \\
2. sinıf & 16 & 17,2 \\
3. sinıf & 24 & 25,8 \\
4. sinıf & 30 & 32,2 \\
\hline TOPLAM & 93 & 100 \\
\hline
\end{tabular}


Uçal Canakay, E. (2021). Müzik öğretmeni adaylarının müziksel dikte yazmaya ilişkin algılarının metaforlar aracıllı̆ıyla incelenmesi. Journal of Human Sciences, 18(4), 665-680. doi:10.14687/jhs.v18i4.6260

\section{Verilerin Toplanmas1}

$\mathrm{Bu}$ araştırmada verilerin toplanması için müzik öğretmeni adaylarına, dikte yazmaya ilişkin algılarını belirleyebilmek amacıyla "dikte yazmak ...... gibidir. Çünkü ......" şeklinde boşluklar bırakılmış bir form dağıtılmıştır. Öğretmen adaylarından ezgisel, armonik ya da ritmik dikte çalışmalarının yapıldığı dersleri, dikte çalışmaları sırasında oluşan sınıf atmosferini, o zamanlarda kendilerini nasıl hissettiklerini, bu çalışmaların onlarda yarattığ duygu durumlarını düşünerek bir metafor oluşturmaları istenmiştir. Ayrıca yazdıkları metaforu neden yazdıklarını belirtmeleri gerektiği hatırlatılmıstır. Dağıtılan formlarda öğretmen adaylarının cinsiyet ve sınıf düzeylerini işaretleyecekleri alan da yer almıştır.

\section{Verilerin Analizi}

Metafor formu ile toplanan verilerin çözümlenmesinde içerik analizinden faydalanılmıştır. "İçerik analizinde temelde yapılan işlem, birbirine benzeyen verileri belirli kavramlar ve temalar çerçevesinde bir araya getirmek ve bunları okuyucunun anlayabileceği bir biçimde organize ederek yorumlamaktur" (Yildırım ve Şimşek, 2000, s. 162). Metaforik çalışmalarda içerik analizi; metafor kodlama ve ayıklama, kategori geliştirme, gegerlik ve güvenirliği săglama, verilerin bilgisayar ortamma aktarlma aşamalarnın uygulanmast ile gerçekleştirilmektedir (Kılcan, 2017, s. 98-104).

Bu çalışmada müzik öğretmeni adaylarının boş bırakılan kısımları doldurduğu cümlede ilk boş alan, dikte yazmanın benzetildiği şey'dir. Diğer boş alanda ise öğretmen adayından yaptı̆̆1 benzetmenin mantıklı bir açıklamasını yazması beklenmektedir. Toplanan verilerde öncelikle cümledeki her iki boş alanın doldurulup doldurulmadığına dair bir kontrol yapılmıs, daha sonra metafor ile açılklama arasında mantıklı bir bağlantı olup olmadığına bakılmıştır. Bu aşamada bu ölçütü sağlamayan 11 veri kapsam dışında bırakılmıs, 82 öğretmen adayından elde edilen verilerle analize devam edilmiştir. Öğretmen adaylarının yazmış olduğu metaforlar listelenerek incelenmesi sürdürülmüsstür.

Metaforların kategorileştirilmesi aşamasında, müzik öğretmeni adaylarının yalnızca geliştirdikleri metaforlar değil, metaforun benzetme yönünün de saptanabilmesi için geliştirilen metafora ilişkin açıklama ile bağlantısı dikkatle incelenmiştir. Bu aşamada 9 kavramsal kategori belirlenmiştir. Araştırmacının belirlediği 9 kategori altında verilen metaforların o kategoriyi temsil edip etmediğini teyit etmek için iki uzmanın görüşüne başvurulmuş ve kategori isimleri uzman görüşlerinin de alınması ile netleştirilmiştir.

Araştırmanın geçerlik ve güvenirliği için, öğretmen adaylarının oluşturmuş olduğu tüm metaforların bulunduğu liste ve araştırmacının oluşturduğu kategorilere göre ayrılmış metafor listesi ve metaforlara ait açıklamalar iki uzman tarafindan incelenmiştir. Görüşüne başvurulan uzmanlardan biri ve araştırmacı arasındaki uyum, Miles ve Huberman'ın formülü ile hesaplanmış (Güvenirlik = Görüş birliği / Görüş birliği + Görüş ayrıllı̆̆1), çıkan sonuç \%90 olarak belirlenmiştir. "Nitel çalışmalarda, uzman ve araştırmacı değerlendirmeleri arasındaki uyumun $\% 90$ ve üzeri olduğu durumlarda arzu edilen düzeyde bir güvenilirlik sağlanmış olmaktadır” (Saban, 2009, s. 288).

Son aşama olarak, tüm veriler bilgisayar ortamına aktarılmış, metaforlara ilişkin frekans ve yüzde hesaplamaları tamamlanmıştır.

\section{BULGULAR}

Müzik öğretmeni adaylarının dikte yazmaya ilişkin ürettikleri metaforlar incelenmiş ve 9 kategoride toplanmıştır. Bu kategoriler şöyle isimlendirilmiştir: mutluluk veren, dikkat gerektiren, çözümleme, karışık duygulara yol açan, somutlaştırma, zorluk, emek ve çaba isteyen, gelişim sağlayan, sıkıntı veren. Öğretmen adaylarının geliştirdikleri metaforlara ilişkin oluşturulan kategoriler Şekil 1'de gösterilmiştir. 
Uçal Canakay, E. (2021). Müzik öğretmeni adaylarının müziksel dikte yazmaya ilişkin algılarının metaforlar aracilığıyla incelenmesi. Journal of Human Sciences, 18(4), 665-680. doi:10.14687/jhs.v18i4.6260

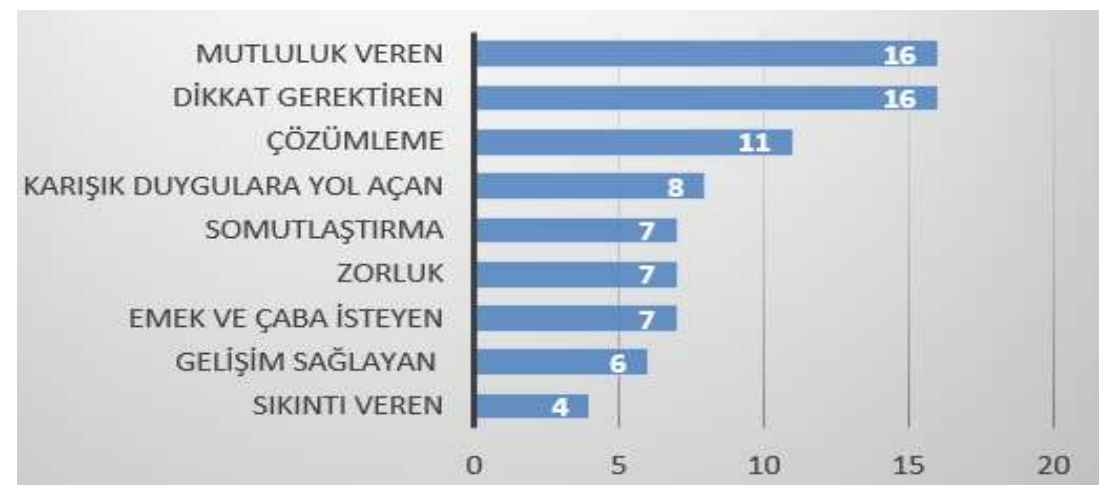

Şekil 1. Müzik öğretmeni adaylarının geliştirdikleri metaforlara ilişkin kategoriler

Tablo 2. Müzik öğretmeni adaylarının dikte yazmaya ilişkin geliştirdikleri metaforların kategorilere göre dağglımı ve frekans ve yüzde değerleri

\begin{tabular}{|c|c|c|c|c|}
\hline Kategori & \multicolumn{2}{|c|}{ Metaforlar } & $f$ & $\%$ \\
\hline \multirow{6}{*}{$\begin{array}{l}\text { Mutluluk veren } \\
\text { (12 metafor) }\end{array}$} & $\begin{array}{l}\text { Bilmece/Bulmaca/Bulmaca } \\
\text { çözmek (3) }\end{array}$ & Mutluluğa ulaşmak için bir yol (1) & \multirow{6}{*}{16} & \multirow{6}{*}{19,51} \\
\hline & $\begin{array}{ll}\text { Matematik } & \text { sorusu/problemi } \\
\text { çözmek (2) } & \\
\end{array}$ & Beyin firtınas1 (1) & & \\
\hline & Doğada yalnız başına yürümek (1) & Bilgisayar oyunu oynamak (1) & & \\
\hline & Bir manzaraya karşı çay içmek (1) & Bulutlar üzerinde yürümek (1) & & \\
\hline & Oyun/Oyun oynamak (2) & Ruhunuzla ilgili bir keşfe çıkmak (1) & & \\
\hline & Büyük rahat bir koltuk (1) & Taç takmak (1) & & \\
\hline \multirow{8}{*}{$\begin{array}{l}\text { Dikkat gerektiren } \\
\text { (15 metafor) }\end{array}$} & Araba sürmek (1) & Denizde yüzmek (1) & \multirow{8}{*}{16} & \multirow{8}{*}{19,51} \\
\hline & Dağda tracking yapmak (1) & Yarışma programı (1) & & \\
\hline & İpte yürümek (1) & Bir çocukla kovalamaca oynamak (1) & & \\
\hline & Kalp ameliyat1 yapmak (1) & $\begin{array}{l}\text { Bilgisayarda strateji oyunu/ Dikkat } \\
\text { oyunu oynamak (2) }\end{array}$ & & \\
\hline & İnişli-çıkışlı bir yolda yürümek (1) & Müzik dinlemek (1) & & \\
\hline & Kamyon sürmek (1) & Seksek oynamak (1) & & \\
\hline & Temizlik yapmak (1) & $\begin{array}{l}\text { Dik ve uzun bir yokuşu korkuyla } \\
\text { tırmanmak (1) }\end{array}$ & & \\
\hline & Bina yapmak (1) & & & \\
\hline \multirow[t]{3}{*}{$\begin{array}{l}\text { Çözümleme } \\
\text { (5 metafor) }\end{array}$} & \begin{tabular}{|ll} 
Bilmece/Bulmaca/Gazetedeki \\
bulmaca & sayfasi/Bulmaca \\
çözmek (7) & \\
\end{tabular} & $\begin{array}{l}\text { Hiç duymadığın bir } \quad \text { konu } \\
\text { ilgilenmek (1) }\end{array}$ & \multirow{3}{*}{11} & \multirow{3}{*}{13,41} \\
\hline & Yap-boz çözmek (1) & Sessiz sinema oynamak (1) & & \\
\hline & Körebe (1) & & & \\
\hline \multirow{4}{*}{$\begin{array}{l}\text { Karışık duygulara } \\
\text { yol açan } \\
\text { (8 metafor) }\end{array}$} & İkizler burcu (1) & İp atlamak (1) & \multirow{4}{*}{8} & \multirow{4}{*}{9,76} \\
\hline & Sürpriz yumurta (1) & Yarısı ekşi yarısı tatlı dondurma (1) & & \\
\hline & Labirent (1) & $\begin{array}{l}\text { Ne yemek olduğunu bilmeden eve aç } \\
\text { gitmek (1) }\end{array}$ & & \\
\hline & Uzun yola çıkmak (1) & Lunaparkta oyuncaklara binmek (1) & & \\
\hline \multirow{3}{*}{$\begin{array}{l}\text { Somutlaştırma } \\
\text { (6 metafor) }\end{array}$} & Tercüme etmek (1) & Bir gizemi çözmek (1) & \multirow{3}{*}{7} & \multirow{3}{*}{8,54} \\
\hline & Renklerin tadını almak (1) & Resim yapmak (2) & & \\
\hline & Anahtar (1) & $\begin{array}{l}\text { Gözle görünmeyen renkleri kağıda } \\
\text { aktarmak (1) }\end{array}$ & & \\
\hline
\end{tabular}


Uçal Canakay, E. (2021). Müzik öğretmeni adaylarının müziksel dikte yazmaya ilişkin algılarının metaforlar aracıllı̆ıyla incelenmesi. Journal of Human Sciences, 18(4), 665-680. doi:10.14687/jhs.v18i4.6260

\begin{tabular}{|c|c|c|c|c|}
\hline \multirow{4}{*}{$\begin{array}{l}\text { Zorluk } \\
\text { (7 metafor) }\end{array}$} & Bulmaca (1) & Yürüyüş yapmak (1) & \multirow{3}{*}{7} & \multirow{3}{*}{8,54} \\
\hline & Matematik problemi çözmek (1) & Trafik kazasından sonraki üzüntü (1) & & \\
\hline & Deveyi hendekten atlatmak (1) & Disleksi hastası olmak (1) & & \\
\hline & Korku filmi izlemek (1) & & & \\
\hline \multirow{4}{*}{$\begin{array}{l}\text { Emek ve çaba } \\
\text { isteyen } \\
\text { ( } 7 \text { metafor) }\end{array}$} & Bulmaca çözmek (1) & Beyin egzersizi (1) & \multirow{4}{*}{7} & \multirow{4}{*}{8,54} \\
\hline & Engelli koşu yarışı (1) & Yürümeyi öğrenmek (1) & & \\
\hline & Açmamış çiçek (1) & Örgü örmek (1) & & \\
\hline & İnşaat (1) & & & \\
\hline \multirow{3}{*}{$\begin{array}{l}\text { Gelişim sağlayan } \\
\text { ( } 6 \text { metafor) }\end{array}$} & Egzersiz yapmak (1) & Kahvaltı (1) & \multirow{3}{*}{6} & \multirow{3}{*}{7,32} \\
\hline & Dikkat ve strateji oyunu (1) & Süt içmek (1) & & \\
\hline & Beyin çalsştırma aktivitesi (1) & Merdiven (1) & & \\
\hline \multirow{2}{*}{$\begin{array}{l}\text { Sikınt1 veren } \\
\text { ( } 4 \text { metafor) }\end{array}$} & Okyanusta yüzmek (1) & Sebze yemek (1) & \multirow[b]{2}{*}{4} & \multirow[b]{2}{*}{4,88} \\
\hline & $\begin{array}{l}\text { Güneşin önüne bulutların } \\
\text { geçmesiyle çöken karanlı (1) }\end{array}$ & Korku (1) & & \\
\hline $\begin{array}{l}\text { TOPLAM } \\
70 \text { metafor }\end{array}$ & & TOPLAM & 82 & 100 \\
\hline
\end{tabular}

Tablo 2 incelendiğinde 82 müzik öğretmeni adayının dikte yazmaya ilişkin toplam 70 metafor ürettikleri ve en stk bilmece/bulmaca/bulmaca çözmek ( $f=12$ ), bilgisayarda strateji oyunu oynamak $(\mathrm{f}=4)$ ve matematik problemi çözmek $(\mathrm{f}=4)$ metaforlarını kullandıkları görülmektedir.

Verilerin analizi aşamasında geliştirilen her bir metaforun benzetme yönünün belirlenmesi için öğretmen adayı tarafindan yazılan gerekçe de incelenmiştir. Böylece bazı metaforların farklı farklı nedenlerle kullanıldığı anlaşılmışır. "Bilmece/Bulmaca/Gazetedeki bulmaca sayfası/Bulmaca çözmek" metaforu "çözümleme" kategorisinde yazılmış (f=7), ayrıca "zorluk" (f=1), "emek ve çaba isteyen" ( $(\mathrm{f}=1)$, "mutluluk veren" ( $\mathrm{f}=3$ ) kategorilerinde de olmak üzere toplam 12 kez kullanılmıştur.

"Bilgisayar oyunu/Dikkat ve strateji oyunu oynamak" metaforu; "dikkat gerektiren" ( $\mathrm{f}=2$ ), "gelişim sağlayan" ( $\mathrm{f}=1)$ ve "mutluluk veren" $(\mathrm{f}=1)$ kategorilerinde olmak üzere toplam 4 kez kullanilmıştır.

"Matematik sorusu/problemi çözmek" metaforu ( $\mathrm{f}=4)$; "zorluk" ( $\mathrm{f}=1$ ) ve "mutluluk veren" $(\mathrm{f}=2)$ kategorilerinde farklı gerekçelerle yer almıştır. "Oyun/Oyun oynamak" ( $\mathrm{f}=2)$ ve "resim yapmak" ( $\mathrm{f}=2$ ) metaforları benzer sebeple üretildiği için aynı kategoride yer almışlardır ve bu metafor toplam 4 kez kullanılmıştır.

Metaforların oluşturduğu kategoriler arasında çeşitlilik bakımından en çok metafor bulunan kategori "dikkat gerektiren" kategorisidir. Bu kategori içerisinde 15 benzersiz metafor yer aldığ1 görülmektedir. Bu kategoriyi 12 metafor ile "mutluluk veren" kategorisi takip etmektedir. Ez az metafor üretilen kategori ise "sıkıntı veren" kategorisidir. Bu kategoride yalnızca 4 metafor yer almaktadir.

\section{Kategori: "Mutluluk veren" kategorisi}

Bu kategori "dikkat gerektiren" kategorisinden sonra ikinci en fazla metaforun yer aldığ kategoridir. Kategori içinde bilmece/bulmaca/bulmaca çözmek ( $f=3)$, matematik sorusu/problemi çözmek ( $\mathrm{f}=2$ ), oyun/ oyun oynamak ( $\mathrm{f}=2$ ) metaforları ilk sıralarda yer almaktadır. Bu metaforları birer frekans değeriyle mutluluğa ulaşmak için bir yol, beyin fırtınası, doğada yalnız başına yürümek, bilgisayar oyunu oynamak, bir manzaraya karşı çay içmek, bulutlar üzerinde yürümek, ruhunuzla ilgili bir keşfe çıkmak, büyük rahat bir koltuk ve taç takmak metaforları izlemektedir.

Bu kategori içinde daha önceki kategorilerde yazılmış olan bilmece/bulmaca/bulmaca çözmek ve matematik sorusu/problemi çözmek metaforları, öğretmen adaylarına mutluluk vermesi gerekçeleriyle karşımıza çıkmışır.

Kategoride yer alan metaforlar ve örnek cümlelerden, öğretmen adaylarının dikte yazma çalışmalarını eğlenceli buldukları ve başarabilmenin onları mutlu ettiği anlaşılabilmektedir. 
Uçal Canakay, E. (2021). Müzik öğretmeni adaylarının müziksel dikte yazmaya ilişkin algılarının metaforlar aracıllı̆ıyla incelenmesi. Journal of Human Sciences, 18(4), 665-680. doi:10.14687/jhs.v18i4.6260

(ÖA 10): "Dikte yazmak bulmaca çözmek gibidir. Çünkü diktelerin tonlarını, donanımlarını bulmak bana eğlenceli geliyor.” ((ÖA 46): "Dikte yazmak bilmece bulmaca gibidir. Çünkü çözümlemeyi, parçalardan bütüne ulaşmayı seviyorum. Hem ritmi hem de sesi aynı anda algılayıp yazmak beni mutlu ediyor." (ÖA 50): "Dikte yazmak bulmaca çözmek gibidir. Çünkü okuduğumuz bölümün en heyecan verici ve keyifli dersidir.” (ÖA 17): “Dikte yazmak oyun gibidir. Çünkü notaları portelere dizmek eğlenceli bir oyundur." (ÖA 92): "Dikte yazmak büyük rahat bir koltuk gibidir. Çünkü dersin öğretmeni sayesinde kendimi güvende ve olmam gereken yerde, çok konforlu hissediyorum.” (ÖA 90): "Dikte yazmak taç takmak gibidir. Çünküdikteyi yazabilirsem hayatımın en önemli işini başarıla bitirmişim hissine kapıllyorum ve sanki biri beni kral tacı gibi bir şeyle ödüllendirmiş hissiyatı yaşıyorum."

\section{Kategori: "Dikkat gerektiren" kategorisi}

Bu kategori en fazla metaforun yer aldığı kategoridir. Bu kategoriyi toplam 16 katılımcı ve 15 metafor temsil etmektedir $(\% 19,51)$. Bu kategoride yer alan bilgisayarda strateji oyunu/dikkat oyunu oynamak metaforunun frekans1 $\mathrm{f}=2$, araba sürmek, bağda tracking yapmak, ipte yürümek, kalp ameliyatı yapmak, inişli-çıkışlı bir yolda yürüme, kamyon sürmek, seksek oynamak, temizlik yapmak, bina yapmak, denizde yüzmek, yarışma programı, bir çocukla kovalamaca oynamak, müzik dinlemek, dik ve uzun bir yokuşu korkuyla turmanmak metaforlanının tamamının frekansı 1'dir.

(ÖA 36): "Dikte yazmak bina yapmak gibidir. Çünkü eksik bir parça olursa o bina çöker. Diktede de küçük bir yanliş herşeyi mahveder." (ÖA 37): "Dikte yazmak bilgisayarda strateji oyunu oynamak gibidir. Çünkü özellikle iki anahtarlı dikte yazarken beynimi ikiye bölüyorum. Oyun oynarken de birçok şeyi aynı anda yapıyorum.” (ÖA 55): "Dikte yazmak ipte yürümek gibidir. Çünkü ufak bir dikkat dağınıklı̆̆ yaşar veya hazır olmadan başlarsanız asla toparlayamazsınız. Ama başarınca da ipte yürümeyi başarmısım gibi beni mutlu ediyor." (ÖA 65): "Dikte yazmak dağda tracking yapmak gibidir. Çünkü bir yerde takıldığınızda tutunacak bir dal (nota) bulamazsak yokuş aşağı düşeriz." (ÖA 69): "Dikte yazmak kalp ameliyatı yapmak gibidir. Çünkü çok fazla dikkat gerektirir ve birkaç işi aynı anda yapmak ve düşünmek gerekir." (ÖA 74): "Dikte yazmak denizde yüzmek gibidir. Çünkü eğlenceli olmasına rağmen aynı zamanda dikkat gerektirir, ufak bir hatada veya panik anında boğulabilirsiniz."

Öğretmen adayları dikte çalışmalarında çok fazla odaklanmak gerektiğini belirten ifadeler yazmışlardır. Geliştirdikleri ipte yürümek, araba sürmek, kalp ameliyatı yapmak gibi metaforlar bu çalışmalarda gösterdikleri dikkati, konsantrosyonu gözler önüne sermektedir.

\section{Kategori: “Çözümleme” kategorisi}

$\mathrm{Bu}$ kategoride 5 metafor yer aldığ ve bu metaforların toplamda 11 kez kullanıldığ görülmektedir. Kategorideki en sık kullanılan metafor $(\mathrm{f}=7)$ Bilmece/Bulmaca/Gazetedeki bulmaca sayfası/Bulmaca çözmek'tir. Kategorideki hiç duymadığın bir konu ile ilgilenmek, yap-boz çözmek, sessiz sinema oynamak ve körebe metaforlanı da dikkate alındığında öğretmen adaylanının dikte çalışmalarını bir bilinmezlik gibi gördükleri ve bu bilinmezliği çözümleme çabası içinde oldukları düşünülebilir. Öğretmen adaylarının "çözümleme" kategorisindeki metaforları neden geliştirdiklerine yönelik gerekçeler aşağıda örnek cümlelerle verilmiştir.

(ÖA 13) 2: "Dikte yazmak bulmaca gibidir. Çünkü her sesin frekansina göre onu bulmaya ve anlamlandırmaya çalışıyoruz." (ÖA 49): "Dikte yazmak gazetedeki bulmaca sayfası gibidir. Çünkü dikte yazarken de bulmaca çözüyor gibi hissediyorum.” (ÖA 40): Dikte yazmak körebe gibidir. Çünkü körebe gibi sesleri bulup yazarı."

\section{Kategori: "Karışık duygulara yol açan" kategorisi}

Bu kategoride her biri 1'er frekans değerinde olan ikizler burcu, sürpriz yumurta, labirent, uzun yola çıkmak, ip atlamak, yarısı ekşi yarısı tatlı dondurma, ne yemek olduğunu bilmeden eve aç gitmek ve lunaparkta oyuncaklara binmek metaforları bulunmaktadır.

(ÖA 20): "Dikte yazmak ikizler burcu gibidir. Çünkükimi zaman zor olur kimi zaman kolay." (ÖA 52): "Dikte yazmak lunaparkta oyuncaklara binmek gibidir. Çünkü çok zevkli ama korkutucu ve

\footnotetext{
2 ÖA 13: Öğretmen adayı 13.
} 
Uçal Canakay, E. (2021). Müzik öğretmeni adaylarının müziksel dikte yazmaya ilişkin algılarının metaforlar aracıllı̆ıyla incelenmesi. Journal of Human Sciences, 18(4), 665-680. doi:10.14687/jhs.v18i4.6260

stresli." (ÖA 60): "Dikte yazmak uzun yola çıkmak gibidir. Çünkü başlamadan önce gerginlik ve sıkıntı yaşatır. Fakat bittiğinde mutlu olursun.” (ÖA 79): “Dikte yazmak ip atlamak gibidir. Çünkü ip atlamak benim için çok keyifli ama aynı zamanda biraz kaygı uyandıran birşeydir. Her an ipe takılıp düşme tehlikesine rağmen ip atlamaktan çok keyif alırım, tıpkı dikte yazmaktan keyif aldığım gibi.”

Bu kategorideki metafor ve örnek cümleler incelendiğinde dikte yazma çalışmalarının öğretmen adaylarına hem olumlu hem de olumsuz duyguları birlikte hissettirdiği söylenebilir.

\section{Kategori: "Somutlaşt1rma" kategorisi}

Bu kategoride 6 metafor bulunmaktadır. Resim yapmak ( $\mathrm{f}=2)$, tercüme etmek ( $\mathrm{f}=1)$, renklerin tadını almak ( $\mathrm{f}=1)$, anahtar ( $\mathrm{f}=1)$, bir gizemi çözmek ( $\mathrm{f}=1)$ ve gözle görünmeyen renkleri kağıda aktarmak ( $\mathrm{f}=1$ ) metaforları bu kategoriyi temsil etmektedir. Bu metaforlar aracilğ̣yla dikte yazmanın öğretmen adayları tarafindan müziği daha anlaşılır hale getiren bir çalışma olarak görüldüğü düşünülebilir. Örnek cümlelere aşağıda yer verilmiştir.

(ÖA 57): "Dikte yazmak bir gizemi cözmek gibidir. Çünkü soyut bir şeyi kağıda dökmek, birbirleriyle ilişki kurmak gerekir." (ÖA 12): "Dikte yazmak tercüme etmek gibidir. Çünkü müziğin dilini insanların anlayabileceği bir şekle çevirmektir." (ÖA 73): "Dikte yazmak resim yapmak gibidir. Çünkü dikteyi yazan kişinin hayalindeki notaları kağıda, porteye aktarıyoruz."

\section{Kategori: "Zorluk" Kategorisi}

Bu kategoride yine bulmaca ( $f=1)$ metaforunun yer aldığı dikkati çekmektedir. Bu kez bu metafor dikte yazmanın zorluğuyla ilişkilendirilerek kullanılmıştır. Kategoride yer alan trafik kazasından sonraki üzüntü, yürüyüss yapmak, disleksi hastası olmak, korku filmi izlemek, deveyi hendekten atlatmak ve matematik problemi çözmek metaforları da birer kez kullanılmışır. Bu kategorideki metaforlar incelendiğinde öğretmen adaylarının dikte yazma çalışmalarında epeyce zorlandıkları söylenebilir.

(ÖA 35): "Dikte yazmak yürüyüș yapmak gibidir. Çünkü İlk başlarda kolay gelir fakat zamanla zorlaşır. Dikte yazmak da başlarda kolay. Ama sınıf atladıkça zorlaşıyor.” (ÖA 42): "Dikte yazmak bulmaca gibidir. Çünkü çözmesi pek kolay değil.” (ÖA 39): "Dikte yazmak deveyi hendekten atlatmak gibidir. Çünkü bu ne kadar zorsa dikte yazmak da benim için o kadar zor." (ÖA 47): "Dikte yazmak matematik problemi çözmek gibidir. Çünkü matematik derslerinde en çok problem çözmekte zorlanırdım. Dikte yazarken de zorlanıyorum."

\section{Kategori: "Emek ve çaba isteyen" kategorisi}

"Emek ve çaba isteyen” kategorisinde bulmaca çözmek, engelli koşu yarışı, açmamış çiçek, inşaat, beyin egzersizi, yürümeyi öğrenmek ve örgü örmek olmak üzere 7 metafor yer almaktadır ve her birinin frekansı $\mathrm{f}=1$ 'dir. Kategoride yer alan metaforlara ilişkin örnek cümleler aşağıda sunulmuştur.

(ÖA 85): "Dikte yazmak beyin egzersizi gibidir. Çünkü sürekli bir çok yönlü düşünme var. Ne olabileceği ile ilgili beyni yormak adeta egzersiz yapmak gibidir." (ÖA 1): "Dikte yazmak açmamıș çiçek gibidir. Çünkü onu sularsam eğer büyütebilirim. Ona bakmazsam, beslemezsem solup gider." (ÖA 33): "Dikte yazmak engelli koșu yarıși gibidir. Çünkü engelleri geçebilirsek sonunda mutlu son bizi bekler. Fakat engelleri geçemez ve takılırsak asla sonuca ulaşamayız."

Bu kategoriye göre öğretmen adaylarının dikte yazmayı çok önem verilmesi gereken bir çalışma olarak gördükleri düşünülebilir. Öğretmen adaylanı, bu çalışmalar için çabalamak gerektiğini, gereken önemi vermezlerse başarılı olamayacakları görüşlerini belirtmişlerdir.

\section{Kategori: “Gelişim sağlayan” kategorisi}

Bu kategoriyi egzersiz yapmak, dikkat ve strateji oyunu, beyin çalıştırma aktivitesi, kahvaltı, süt içmek ve merdiven olmak üzere 6 metafor temsil etmektedir. Metaforların her birinin frekans değeri 1'dir.

(ÖA 5): "Dikte yazmak merdiven gibidir. Çünkü temel bilgileri bilmeden dikte yazamayız. Bu derste bilgilerimizi basamak basamak üst üste koyarak dikte yazmayı öğreniriz." (ÖA 45): "Dikte yazmak süt içmek gibidir. Çünkü süt içmek çocukların gelişim döneminde vücutlarını geliştirir. Dikte de bu şekilde kulağımızı geliştirir." (ÖA 68): "Dikte yazmak egzersiz yapmak gibidir. Çünkü nasıl sporcular formdan düşmemek için her gün egzersiz yapiyorsa bizim egzersizimiz de diktedir." 
Uçal Canakay, E. (2021). Müzik öğretmeni adaylarının müziksel dikte yazmaya ilişkin algılarının metaforlar aracıllğıyla incelenmesi. Journal of Human Sciences, 18(4), 665-680. doi:10.14687/jhs.v18i4.6260

Bu kategoride yer alan metaforlar ve örnek cümlelere bakıldığında, ögretmen adaylarının dikte çalışmalarını süt içmek gibi, kahvaltı gibi ya da vücut egzersizi gibi çok faydalı bulduğu söylenebilir. Dikte yazarken temel müzik bilgilerini de kullandıkları için bu çalışmaları kendilerini geliştirme konusunda işe yarar buldukları düşünülebilir.

\section{Kategori: "S1knt1 veren" Kategorisi}

Bu kategori öğretmen adaylarının dikte yazmaya ilişkin en az metafor geliştirdikleri kategoridir. İçinde yer alan metaforlar okyanusta yüzmek $(\mathrm{f}=1)$, sebze yemek $(\mathrm{f}=1)$, korku (f=1) ve güneşin önüne bulutların geçmesiyle çöken karanlık ( $\mathrm{f}=1)$ metaforlarıdır.

(ÖA 27): "Dikte yazmak korku gibidir. Çünkü eksiklerimin olduğu çok şey var. Bu yüzden çalışmaktan zevk almıyorum, Derslerde de korkuyorum." (ÖA 80): "Dikte yazmak güneșin önüne bulutların geçmesiyle çöken karanlık gibidir. Çünkü bazen dikteyi bir yere kadar sorunsuz yazabilirken bir anda ölçüyü duyamama sonucu karanlık, kargaşa ve boşlukta kaybolma gibi şeyler yaşıyorum."

Kategoride yer alan metaforlar ve örnek cümleler aracıllı̆ıyla, öğretmen adaylarının çeşitli sebepler nedeniyle dikte yazmayla ilgili olumsuz duygular yaşayabildikleri söylenebilir.

Çalışmada ayrıca müzik öğretmeni adaylarının dikte yazmaya ilişkin oluşturdukları metaforlara ilişkin kelime bulutu oluşturulmuştur. Oluşturulan kelime bulutu Şekil 2'de verilmiştir.

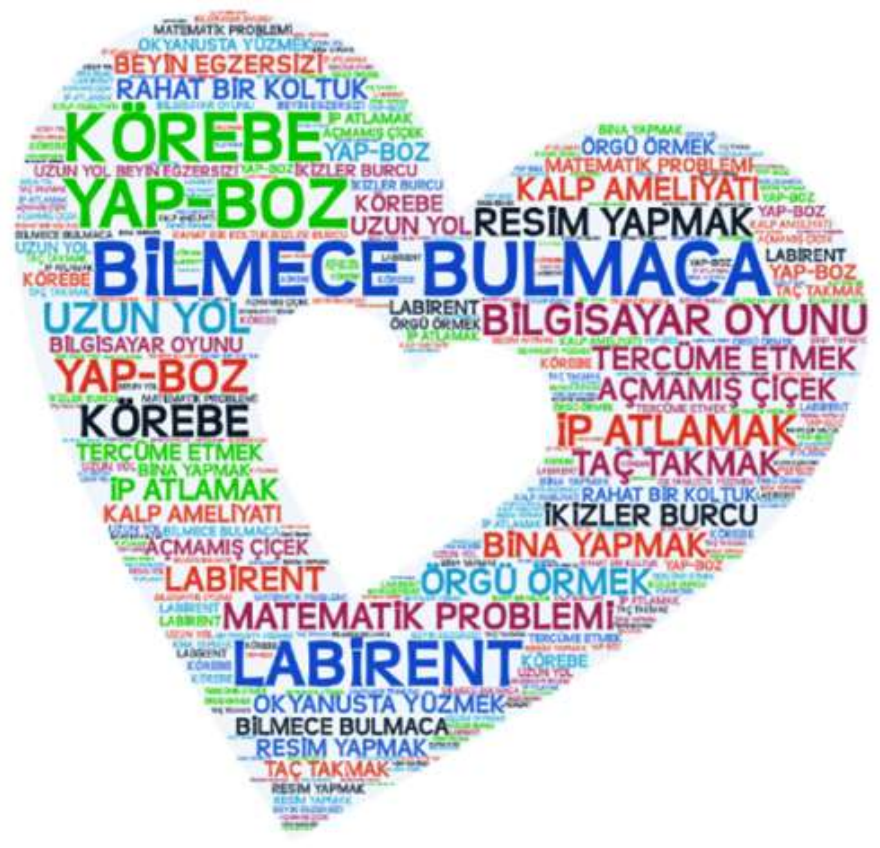

Şekil 2. Müzik öğretmeni adaylarının dikte yazmaya ilişkin oluşturdukları metaforlara ilişkin kelime bulutu

\section{SONUÇ VE TARTIŞMA}

Araştırma kapsamında; müzik öğretmeni adaylarının müziksel işitme alanının önemli bir boyutu olan dikte yazmaya ilişkin algılanının metaforlar aracllığıla belirlenmesi amaçlanmıştır. Bu doğrultuda; 93 müzik öğretmeni aday1 müziksel dikte yazmaya ilişkin 70 metafor geliştirmiştir. Öğretmen adaylanını geliştirdikleri bu metaforlar çözümleme, zorluk, somutlaştırma, dikkat gerektiren, emek ve çaba isteyen, gelişim sağlayan, karşılk duygulara yol açan, mutluluk veren, sıkıntı veren olmak üzere 9 kategoride toplanmıştır.

“Çözümleme” kategorisinde öğretmen adayları dikte yazmayı en fazla bilmece/bulmaca çözme etkinliğine benzetmişlerdir. Bilmece/Bulmaca oyunları hem günlük yaşantıda hem de eğitim programlarında zihinsel becerilerin geliştirilmesine yönelik sıkça kullanılan materyallerdir. Başerer (2021), yaptığı çalışmada mantıksal düşünmeyi geliştiren etkinlikler içinde bilmecelere ve bulmacalara 
Uçal Canakay, E. (2021). Müzik öğretmeni adaylarının müziksel dikte yazmaya ilişkin algılarının metaforlar aracıllı̆ıyla incelenmesi. Journal of Human Sciences, 18(4), 665-680. doi:10.14687/ihs.v18i4.6260

ayrı ayrı yer vermiştir. Bilmeceler ve bulmacalar, verilen ipuçlarından yola çıkarak bilinmeyeni bulmaya kadar olan süreçte pek çok zihinsel faaliyetin gerçekleştiği etkinliklerdir. Dikte yazma çalışmalarında da genellikle verilen "la" kılavuz sesinden yola çıkılır ve öncelikle parçanın tamamı baştan sona dinlenir. Ardından genellikle ikişer ölçü tek tek dinlenir ve tonal yapının sunduğu tüm ipuçları dikkate alınarak bütün oluşturulur. Burada tümevarım, tümdengelim, analitik düşünme süreçlerinin hepsi birden yer alır. Öğretmen adaylarının dikte yazma çalışmalarını bilmece/bulmaca çözme etkinliğine benzeterek açıklamaya çalısmalarının bu zihinsel süreçleri dikkate almalarından kaynaklandığ1 düşünülmektedir.

Araştırmada belirlenen "somutlastırma" kategorisinin, "cö̊ümleme" kategorisi ile çok bağlantılı olduğu düşünülmektedir. Burada da öğretmen adayları ilişki kurmak, bir gizemi çözmek, gözle görülür hale getirmek gibi süreçlerden söz etmektedir. Öğretmen adayları anahtar, renklerin tadını almak, resim yapmak, tercüme etmek, bir gizemi çözmek, gözle görünmeyen renkleri kağıda aktarmak metaforları ile zihinsel olarak çözümlenmiş olanların, somut hale getirilmesi düşüncelerini öne çıkarmışlardır. Çünkü dikte yazma sürecinde duydukları sesleri yüksekliklerine göre anlamlandırıp dizek üzerine yerleştirir ve seslerin sürelerine göre gruplandırmalar yaparak ritmik değerleri oluştururlar. Bu yönüyle dikte yazmak; öğretmen adaylarının metaforlarında da belirttiği gibi, dizek üzerinde melodilerin resmini yapmaktur.

"Dikkat gerektiren" kategorisi, bu araştırmada tüm metaforları en yüksek oranda ( $f=16$, $\% 19,51)$ temsil eden kategoridir. Bu kategori içerisinde yer alan tüm metaforların açılama cümleleri, gerçekleştirilen eylemi en üst seviyede dikkat ile yapmak gerektiğini anlatmaya çalısır niteliktedir. Ögrretmen adaylarından biri, dikte yazmayı kalp amelivatı yapmak gibi büyük dikkat ve sorumluluk gerektiren bir eyleme benzetmiştir. Öğretmen adaylarının, dikte yazarken çok dikkat etmezseniz herşey alt üst olabilir, yaptı̆̆ınız bina çökebilir ya da denizde boğulabilirsiniz biçimindeki örnek ifadeleri çok çarpıcıdır.

Müzik öğretmeni adayları “emek ve çaba isteyen” kategorisi içinde dikte yazmayı, mesleki olarak çok önemli bulduklarından temeli iyi atmak gerektiğini ve düzenli çalısmak gerektiğini vurgulamışlardır. Ataman'ın da belirttiği gibi (2013: 459), anadilde duyulan sözcük ve cümleleri yazıya geçirebilmek ne derece önemliyse, müziksel yazma becerisi de aynı derecede önemlidir.

Araştırmada yer alan "emek ve çaba isteyen" kategorisi, içinde yer alan metaforlarla birlikte değerlendirildiğinde Düzgören ve Gerekten’in (2017) araştırmasının sonuçlarından biriyle örtüşmekte olduğu görülmektedir. Düzgören ve Gerekten'in yaptığı çalışmada Anadolu Lisesi öğrencilerinin 'Müzik Dersi' kavramına ilişkin algıları metaforlar aracılığı ile belirlenmiştir. Araştırma sonuçlarına göre öğrenciler, 'Müzik Dersi' kavramını, daha çok 'Hayat', 'Yemek', 'Aşk', 'Nefes', gibi metaforlar ile açıklamışlardır. Bu araştırmada belirlenen "Müzik Dersi Çalışma Gerektirir" kategorisinde yer alan çiçek metaforu dikkat çekmektedir. Öğrencilerin bu metaforu müzik dersinin dikkat, ilgi, çalışma isteyen bir ders olduğunu vurgulaması sebebiyle tercih ettikleri ifade edilmiştir. Bazı öğrencilerin görüşleri şu şekildedir: "Müzik Dersi çiçek gibidir, çünkü; suladığın zaman açar, sulamadığında kurur. İlgi ve dikkat ister.", "Müzik Dersi çiçek gibidir, çünkü; üstüne düşüp ilgilendikçe yani bir çiçeği sularsak nasıl renkli bir şekilde açarsa müzik dersi de daha çekici bir hal alır." Bu araştırmada da müzik eğitimi içinde yer alan dikte yazma çalışmaları ile ilgili olarak "emek ve çaba isteyen" kategorisinde 'asmamus çiçek' metaforu dikkat çekmektedir.

"Gelişim sağlayan" kategorisi, 6 metafor içermektedir. Bu kategoride yer alan metaforlar ve örnek cümleler, öğretmen adaylarının dikte yazma çalısmalarını mesleki gelişimlerinde kendilerini daha üst seviyelere çıkaracak bir alan olarak gördüklerini düşündürmektedir. Dikte yazma çalısmaları; müzik teorisi ve müziksel okuma çalışmalarıyla birlikte ele alındığında müzik öğretmeni adaylarının şark1 söyleme, çalg1 çalma ve müziksel yaratım çalışmalarını doğrudan etkileyebilecek güçte çalışmalardır. Yapılan bir çalışmada müziksel işitme okuma ve yazma eğitiminin keman eğitimine etkilerinin araştırılması amaçlanmıştır. Araştırmanın genel sonuçlarına bakıldığında müziksel işitme, okuma ve yazma eğitiminin keman çalmada entonasyon, çift ses çalma, etüd ve serlerde hızlı deşifre, ton değişimlerini algılama ve adapte olmada olumlu yönde katkısı olduğu görülmektedir (Şendurur ve Tanınmış, 2017). 
Uçal Canakay, E. (2021). Müzik öğretmeni adaylarının müziksel dikte yazmaya ilişkin algılarının metaforlar aracıllı̆ıyla incelenmesi. Journal of Human Sciences, 18(4), 665-680. doi:10.14687/jhs.v18i4.6260

Araştırmada belirlenen kategorilerden bir diğeri “mutluluk veren” kategorisidir. Bu kategori, en fazla metafor alan kategori bakımından ikinci sırada yer almaktadır. Bu sonuç, öğretmen adaylarının müziğin içinde olmaktan, müziksel dikte yazmaktan keyif aldıklarını göstermektedir. Burada bir öğretmen adayının (ÖA 90) "Dikte yazmak taç takmak gibidir. Çünkü dikteyi yazabilirsem hayatımın en önemli işini başarıyla bitirmişim hissine kapıllyorum ve sanki biri beni kral tacı gibi bir şeyle ödüllendirmiş hissiyatı yaşıyorum” ifadeleri dikkat çekmektedir. Öğretmen adayının dikteyi başarıyla tamamlamayı, kral tacı takmayla eşleştirdiği görülmektedir. Bu durum, başarılı olmanın yarattı̆̆ tatmin duygusundan kaynaklanmış olabilir. "Mutluluk veren” kategorisinde bir öğretmen adayının yazdığ1 cümle şu şekildedir: (ÖA 92) "Dikte yazmak büyük rahat bir koltuk gibidir. Çünkü dersin öğretmeni sayesinde kendimi güvende ve olmam gereken yerde, çok konforlu hissediyorum.” Bu durum, olumlu sınıf atmosferi oluşturmanın önemine işaret etmektedir. Bu çalışmaların yapıldığı derslerde öğrencilerin gergin, huzursuz, kaygilı olmamaları, kendilerini rahat hissetmeleri dikte yazmaya odaklanmalarını kolaylaştıracaktır. Bu nedenle eğitmenlerin dikte yazdırırken pozitif bir sınıf atmosferi sağlamaları önerilmektedir.

Araştırmanın bu sonucu Sözbir ve Çakmak'ın araştırmasının (2016) bir sonucuyla da örtüşmektedir. Araştırmacılar, okul öncesi öğretmen adaylarının müzik ile ilgili algılarının metaforlar aracilığıyla ortaya çıkarılması amacıyla 86 öğretmen adayı üzerinde bir araştırma yapmışlardır. Müzik kavramının en çok 'hayat' metaforu ile tanımlandığı bu çalışmada belirlenen 11 kategoriden birisi "huzur veren" kategorisidir.

Nitelikli bir müzik öğretmenin yetişmesinde çok büyük etkisi olan müziksel dikte çalışmaları, öğretmen adayları tarafindan zorlayıcı bir konu olarak da algılanmaktadır. Dikte yazmayı zor bulan öğretmen adaylarının geliştirdiği metaforlar, "zorluk" kategorisinde toplanmıştır. Öğretmen adaylarından biri, dikte yazmayı temposu gittikçe artan bir yürüyüş gibi algılamış, düşüncesini şöyle dile getirmiştir: (ÖA 35) "İlk başlarda kolay gelir fakat zamanla zorlaşır. Dikte yazmak da başlarda kolay. Ama sınıf atladıkça zorlaşıyor.” Kategorideki diğer metaforlar trafik kazasından sonraki üzüntü, bulmaca (çözmesi kolay olmayan bir bulmaca), disleksi hastası olmak (seslerin karışık ve ters algilanması açısından), deveyi hendekten atlatmak ve matematik problemi çözmek (problemi çözerken zorlanmak açısından) olarak belirtilmiştir. Trafik kazasından sonraki üzüntü metaforunu yazan öğretmen adayı (ÖA 8), düşüncesini şu şekilde ifade etmiştir: "Dikte çok zor bir şey, beceremiyorum ve bunun sonucunda da inanılmaz üzülüyorum." Bu öğretmen adayının, dikte yazmanın zorluğunu çok yoğun hissetmesi ve beceremediği için büyük bir üzüntü yaşaması çok olumsuz bir metafor ile dile getirilmiştir. Bu öğretmen adayı ile benzer duygu ve düşüncelere sahip olan başka müzik öğretmeni adaylarının da olabileceği düşünüldüğünde, müziksel işitme eğitiminin verildiği derslerin eğitmenlerinin öğrencilerinin bu algıları konusunda hassasiyet göstermeleri gerektiği açıktır. Eğitmenler, öğrencilerinin derse karşı tutumlarını yakından izlemelidir ve eğitim süreçlerini planlarken öğrenci tutumlarını mutlaka göz önünde bulundurmalıdır.

Araştırmanın sonuçlarına göre dikte yazma çalışmalarının bir müzik öğretmeninin yetişmesi için çok önemli olduğu, çalışmaların yoğun emek, çaba ve dikkat gerektiği söylenebilir. Sonuçlar incelendiğinde müzik öğretmen adaylarının bu çalışmalara keyifle, eğlenerek katıldıkları görülmüştür. Öğretmen adayları, kendilerini geliştirdiklerini düşündükleri bu çalışmalarda mutlu olduklarını ve huzurlu hissettiklerini dile getirmişlerdir. Ancak bu çalışmada dikte yazmayla ilgili olarak olumsuz görüşlerini belirten öğretmen adayları da olmuştur ( $\mathrm{f}=4)$. "Sıkıntı veren" kategorisinde yer alan metaforlar için yapılan açıklamalarda heyecan, korku, panik, boşlukta kaybolma, karanlık, kargaşa gibi ifadeler yazılmıştır. Bu ifadeler düşündürücü ve çok üzüntü vericidir.

Öğrenme ortamında oluşan pozitif duyguların öğrenmeyi kolaylaştırdığı bilinmektedir (Ocak Karabay ve Şahin Ası, 2019; Akhan ve Kaymak, 2019). Çünkü bireyler, kendilerini mutlu hissettikleri anlara geri dönüp o andaki duygularını tekrar hissetmek isterler, olumsuz duygular hissettikleri anları ise unutmaya meyillidirler. Pozitif duygulara sebep olan öğrenme ortamlarının akılda kalması, o ortamda konuşulanların, çalışılan konuların, öğrenilen bilgilerin hatırlanmasını kolaylaştırır. Müzik öğretmeni adaylarının kendilerini iyi hissetmelerini sağlayacak biçimde pozitif bir öğrenme ortamının 
Uçal Canakay, E. (2021). Müzik öğretmeni adaylarının müziksel dikte yazmaya ilişkin algılarının metaforlar aracıllı̆ıyla incelenmesi. Journal of Human Sciences, 18(4), 665-680. doi:10.14687/jhs.v18i4.6260

sunulması ile onların derse istekle gelmelerinin sağlanmasının yanı sıra, edindikleri bilgileri de kolay hatırlamalarına destek olunacaktur.

Metaforlar duygu ve düşüncelerin belirlenmesinde etkili bir araçtır. Bu çalışmada müzik ögretmeni adaylarının dikte yazmaya yönelik algılarının belirlenmesinde metaforlardan faydalanılmış ve önemli bilgiler elde edilmiştir.

Bu çalışma kapsamında öğretmen adaylarının dikte yazmayla ilgili hem olumlu hem de olumsuz algılarını anlatmaya çalışan metaforlar da saptanmıştır ve "karışık duygulara yol açan" kategorisinde sunulmuştur ( $\mathrm{f}=8$ ). Müzik öğretmeni adaylarının iyi bir müzik öğretmeni olabilmek için önemli buldukları bu çalışmaları sevmeleri, fakat aynı zamanda da çok fazla çaba gerektirdiği ve bazen de başarmakta zorlandıkları için sevmediklerini düşünmeleri çok olağan karşılanabilecek bir durumdur.

Araştırmada elde edilen sonuçlar değerlendirildiğinde, öğretmen adaylarının eğitmenleri rehberliğinde dikte yazma çalısmalarının gerekliliği ile ilgili farkındalıklarının sağlanması önemli görülmektedir. Öğretmen adaylarının eğitim yaşantılarında bilinçli bir şekilde yol almalarına yardımcı olmak ve zorlandıkları durumlarda onlara destek olmak eğitmenlerin ihmal etmemesi gereken konulardır. Ayrıca müziksel işitme alanında çalışan eğitmenlere derslere karşı ilgi ve motivasyonun sürekliliğini sağlayabilmek için farklı öğretim yöntem ve yaklaşımlarının kullanılması, öğretmen adaylarının başarı düzeylerinin yükseltilebilmesi için alana özgü çalışma metotlarının araştırlması, güncel yayınların takip edilmesi ve derslerde uygulanması, ders içeriklerinin belli periyodlarda güncellenmesi önerilmektedir. Bu sayede olumsuz duygu ve düşüncelerin olumlu olması yönünde bir ilerleme sağlanabileceği düşünülmektedir.

\section{KAYNAKÇA}

Akhan, N. E. ve Kaymak, B. (2019). Sosyal bilgiler öğretmen adaylarının fakültelerindeki öğrenme ortamlanına yönelik görüşleri. Journal of History School, 43, 1503-1534. doi: 10.29228/Joh24729

Arslan, M. M. ve Bayrakçı, M. (2006). Metaforik düşünme ve öğrenme yaklaşımının eğitim-öğretim açısından incelenmesi, Milli Ë̆itim Dergisi, 171, 100-108. Erişim adresi: http://dhgm-dotmeb-dot-gov-dot-

tr.gateway.web.tr/yayimlar/dergiler/Milli_Egitim_Dergisi/171/171/8.pdf

Ataman, Ö. G. (2013). Müzik öğretmeni adaylarının müziksel işitme okuma yazma dersleri başarılarının bazı değişkenler açısından incelenmesi (Balıkesir Üniversitesi örneği), Eŭgitim Fakültesi Dergisi, $26 \quad$ (2), 455-471. $\quad$ Erişim adresi: https://dergipark.org.tr/tr/download/article-file/153512

Aydın, İ. H. (2004). Bir felsefî metafor "Yolda olmak", Din Bilimleri Akademik Arastırma Dergisi, 6(4), 9-22. Erişim adresi: https://dergipark.org.tr/tr/download/article-file/52469

Babacan, E. (2014). AGSL öğrencilerinin müzik kavramına ilişkin algıları: metafor analizi. Eğgitim ve Öğretim Arasturmalar Dergisi, 3 (1), 124-132. Erişim adresi: http://www.jret.org/FileUpload/ks281142/File/12.babacan.pdf

Başerer, D. (2021). Mantıksal düşünmeyi geliştiren etkinlik örnekleri. Millı Eğitim Dergisi, 50 (231), 335-352. doi: 10.37669/milliegitim.727874

Botha, E. (2009). Why metaphor matters in education, South African Journal of Education, 29, 431 444. doi: $10.15700 /$ saje.v29n4a287

Bozpolat, E. (2016). Öğretmen adaylarının lisansüstü eğitime ilişkin metaforik algıları, Elementary Education Online, 15(4), 1114-1130. doi: http://dx.doi.org/10.17051/io.2016.90433

Büyükalan, S. ve Yaylac1, Z. (2018). Normal gelişim gösteren öğrencileri ile kaynaştırma öğrencilerinin sosyal bilgiler kavramına ilişkin metafor algıları. Ankara Üniversitesi Ĕ̈itim Bilimleri Fakültesi Ö̊rel Ë̆itim Dergisi, 19 (4), 679-697. doi: 10.21565/ozelegitimdergisi.376764

Demirbilek, N. ve Atila, F. (2021). Fen edebiyat fakültesi öğrencilerinin bilim kavramına ilişkin metaforik alg1lar1. Atatürk Üniversitesi Kaحım Karabekir Ë̈itim Fakültesi Dergisi, 42, 415-430. doi: 10.33418/ataunikkefd.835347 
Uçal Canakay, E. (2021). Müzik öğretmeni adaylarının müziksel dikte yazmaya ilişkin algılarının metaforlar aracıllğıyla incelenmesi. Journal of Human Sciences, 18(4), 665-680. doi:10.14687/jhs.v18i4.6260

Düzgören, H. ve Gerekten, S. E. (2017). Anadolu lisesi öğrencilerinin 'müzik dersi' kavramına ilişkin algıları. Online Journal Of Music Sciences, 2 (3), 86-117. Erişim adresi: https://dergipark.org.tr/tr/download/article-file/398403

Kilcan, B. (Ed.). (2017). Metafor ve eğitimde metaforik çalşsmalar için bir uygulama rehberi (s: 93-112). Kilcan, B. (Ed.). Ankara: Pegem Yayincilik.

Kılcan, B., Akbaba, B. ve Gülbudak, B. (2017). Altıncı ve yedinci sınıf öğrencilerinin Hoca Ahmed Yesevî algilar1. Journal of History Culture and Art Research, 6 (2), 549-564. doi: 10.7596/taksad.v6i2.809

Lakoff, G. (1993). The contemporary theory of metaphor, Erişim adresi: https://escholarship.org/content/qt54g7j6zh/qt54g7j6zh.pdf

Ocak Karabay, Ş. ve Şahin Ası, D. (2019). Okul öncesi öğretmenleri sınıftaki farklı durumlarla nasıl başa çıkıyorlar? Öğretmen bildirimlerine dayalı bir çalışma. Uşak Üniversitesi Ĕgitim Araştirmalar $\quad$ Dergisi, 5 (1), 87-108. Erişim adresi: https://dergipark.org.tr/en/pub/usakead/issue/45560/461443

Özevin, B. ve Kaya, A. (2019). Okul öncesi öğretmen adaylarının öğretmen kavramına ilişkin metaforik alg1ları. Erįincan Üniversitesi Eğitim Fakültesi Dergisi, 22 (3), 691-707. doi: 10.17556/erziefd.653091

Patton, M. Q. (2018). Nitel araştrma ve değerlendirme yöntemleri. Tütün, M. ve Demir, S. B. (Çev. Ed.). Ankara: Pegem Yayıncilik.

Powell, J. (2013). Melodic dictation: An examination of strategy and time usage by college music students. Southern Methodist University, Unpublished Master Thesis, UMI Number: 1543369.

Saban, A. (2002). Sınıf öğretmeni adaylarının ilkokula ilişkin en çok hatırladıkları ve en çok tercih ettikleri metaforlar. Eğitim Bilimleri ve Uygulama, 1 (2), 211-223. Erişim adresi: http://www.ebuline.com/pdfs/2sayi/2-5.pdf

Saban, A. (2008). Okula ilişkin metaforlar, Kuram ve Uygulamada Eğitim Yönetimi, 55, 459-496. Erişim adresi: https://dergipark.org.tr/tr/pub/kuey/issue/10342/126702

Saban, A. (2009). Öğretmen adaylarının öğrenci kavramına ilişkin sahip oldukları zihinsel imgeler. Türk Eğitim Bilimleri Dergisi, 7 (2), 281-326. Erişim adresi: https://dergipark.org.tr/tr/pub/tebd/issue/26107/275061

Saylık, A., Saylık, N. ve Sağlam, A. (2021). Eğitimcilerin gözünden Türk eğitim sistemi: bir metafor çalışması. Yüräncü Yll Üniversitesi Eğitim Fakültesi Dergisi, 18 (1), 522-546. doi: 10.33711 /yyuefd. 919424

Sözbir, S. A. ve Çakmak, Ö. C.. (2016). Okul öncesi öğretmen adaylarının “müzik” kavramına ilişkin metaforik algilan1, The Journal of Academic Social Science Studies, 42, 269-282. doi: 10.9761/JASSS3248

Şahin-Kalyon, D. ve Aksoy, P. (2017). Pre-service primary school teachers' perceptions of the concept of drama: a metaphor study. SDU International Journal of Educational Studies, 4(2), 110 126. Erişim adresi: https://dergipark.org.tr/tr/pub/sduijes/issue/32846/357550

Şahin, A. (2018). Eğitimde bilişim teknolojisi kullanımına ilişkin öğretmen görüşleri: Adıyaman Üniversitesi Sosyal Bilimler Enstitüsü Dergisi, 11 (31), 121-159. doi: 10.14520/adyusbd.492882

Şendurur, B.İ. ve Tanınmış G.E., (2017). Müziksel işitme okuma ve yazma eğitiminin keman eğitimine etkisi, Fine Arts (NWSAFA), 12(3):185-198, doi: 10.12739/NWSA.2017.12.3.D0199.

Ulusoy, B. (2020). 8. sınıf öğrencilerinin liselere geçiş sınavı (LGS)'na ilişkin algılarının metaforlar arac1llğılla incelenmesi. Necmettin Erbakan Üniversitesi Ereğli Eğitim Fakültesi Dergisi, 2 (2), 186 202. doi: 10.51119 /ereegf.2020.5

Yıldırım, A. ve Şimşek, H. (2000). Sosyal bilimlerde nitel araştırma yöntemleri. Ankara: Seçkin Yayıncilık. 
Uçal Canakay, E. (2021). Müzik öğretmeni adaylarının müziksel dikte yazmaya ilişkin algılarının metaforlar aracıllı̆ıyla incelenmesi. Journal of Human Sciences, 18(4), 665-680. doi:10.14687/ihs.v18i4.6260

\section{Extended English Summary}

\section{Introduction}

The field of musical hearing education is among the most significant areas due to its importance in prospective music teachers' learning experiences. This is because musical hearing has an effect the success on all other areas of musical education. The studies on dictation writing have had placed, as the longest duration in musical hearing courses. While writing dictation, students should use all hearing abilities in the highest levels. It is important to determine the prospective music teachers' evaluation on studies of dictation writing for its direct effect on many courses in their occupational training and musical development.

In recent years, it has been seen that metaphors used in educational studies, which refer the student, teacher or prospective teachers' feeling, ideas and opinions. Metaphors are strong means of expression. Besides, also in learning environment metaphorical idea and metaphorical expression took place often. Saban connoted that metaphors can be used as "pedagogic mean" for definite facts revealing, understanding and maybe changing of their mind images during the education of prospective teachers (2008, p. 490).

Metaphor is used for a better and more beautiful explanation of a concept, word, term, fact by simulate it to another word means different than the simulated (Aydin, 2004, p.10). They are helping to get easier understandings on fact and concepts that are abstract, complex and hard to explain by simulating and doing connotations. Botha (2009, p. 431) stated that metaphors are playing important roles aesthetically and pedagogically in education also besides literature.

There are studies working on different perceptions on different concepts of individuals by using metaphors in the context of educational sciences and in different levels of education. In literature review, it is found out that less research made, which are using metaphors as data collection tool in music education field than the other education fields. For that reason, in this research it is deem suitable to get benefit from using metaphors of prospective music teachers' perceptions on musical dictation writing.

\section{Method}

The working group of this research consists of 68 females, 25 males, which are 93 students totally, which are studying in the $1^{\text {st }}, 2^{\text {nd }}, 3^{\text {rd }}$ and $4^{\text {th }}$ grades of the Music Education Sub-branch in the Department of Fine Arts Education in Buca Faculty of Education at Dokuz Eylul University in the 2018-2019 educational year.

The data of this research has been collected with a fill in the blanks form like "dictation writing is like ....... Because ......". Data collected analyzed by using content analysis. "Basically in content analysis the similar data grouped in specific concept and themes, organized and interpreted in the way the reader can understand" (Yildırım and Simsek, 2000, p. 162). In collected data initially a check on fill in the blanks made, then a reasonable connection between metaphor and the explanation searched. In this stage 11 data excluded because not suited to the criteria, and content analysis made by using the 82 prospective teachers' data collected.

After the listing and categorizing of the metaphors, expert interviews have been made. Miles and Huberman's formula used to define research reliability and validity (Reliability = Agreements / Agreements + Disagreements), and the finding result was 90\%.

\section{Findings, Discussion and Results}

Finding results shows that 82 prospective music teachers have produced 70 metaphors on dictation writing. Prospective music teachers produced metaphors on dictation writing categorized in 9, which are (19,51\%) giving happiness, (19,51\%) needs attention, (13,41\%) analysis, (9,76\%) caused mixed emotions, (8,54\%) concreting, (8,54\%) difficulty, (8,54\%) needs effort, (7,32\%) developing, and (4,88\%) troublesome. It is found out that prospective teachers used metaphors like puzzle / crossword / puzzle solving $(\mathrm{f}=12)$, playing strategy game on computer $(\mathrm{f}=4)$ and solving math problems $(\mathrm{f}=4)$. 
Uçal Canakay, E. (2021). Müzik öğretmeni adaylarının müziksel dikte yazmaya ilişkin algılarının metaforlar aracıllı̆ıyla incelenmesi. Journal of Human Sciences, 18(4), 665-680. doi:10.14687/jhs.v18i4.6260

"Need attention" category is the part the most metaphors are in. This category representing by 16 attendant and 15 metaphors (19,51\%). In this category playing strategy game / attention game on computer metaphor's frequency $\mathrm{f}=2$, all the metaphors' frequency is 1 , which are driving, tracking in wine yard, walking a tightrope, making a heart surgery, walking on a bumpy road, driving a truck, playing a hopscotch, housekeeping, building, swimming, quiz show, playing chase, listening to music, and climbing a high and steep hill with frightening. "Giving happiness" category is the second one as the most after the "needs attention" category. In this category puzzle / crossword / puzzle solving $(\mathrm{f}=3)$, math question / problem solving $(\mathrm{f}=2)$, play / playing $(\mathrm{f}=2)$ are in first places. These metaphors are fallowed by these metaphors with 1 difference: A way to happiness, brain storming, walking alone in nature, playing computer games, drinking tea to a view, walking on clouds, go for exploring your soul, big comfortable chair and crowning. In "analysis" category there are 5 metaphors, which are used for 11 times. The most used metaphor in this category is puzzle / crossword / puzzle sheet in newspaper / puzzle solving ( $\mathrm{f}=7$ ). In the "causing mixed emotions" category there are Gemini sign, surprise egg, labyrinth, road trip, jump rope, sweet sour ice cream, going hungry to home by not knowing what is on dinner, and ride on toys at amusement park, which each frequencies are 1. In "concreting" category there are 6 metaphors. Painting $(\mathrm{f}=2)$, translating $(\mathrm{f}=1)$, tasting the colors $(\mathrm{f}=1)$, key $(\mathrm{f}=1)$, solving a mystery $(\mathrm{f}=1)$ and transferring unseen colors to paper $(\mathrm{f}=1)$ metaphors are representing this category. In "difficulty" category there is still the puzzle $(\mathrm{f}=1)$ metaphor that draws attention. This time metaphor used related to the difficulty of dictation writing. The metaphors in this category used only ones are the sadness after the car crash, walking around, being dyslexia, watching horror movie, dodge the camel and solving math problem. In "needs effort" category there are 7 metaphors, which are solving a puzzle, running a steeplechase, unopened flower, construction, brain exercise, learning to walk and knitting with each frequencies $\mathrm{f}=1$. In "developing" category there are 6 metaphors, which are doing exercises, playing attention and strategy game, brain working activity, breakfast, drinking milk and staircase. Each metaphor's frequencies are 1. The "troublesome" category is the least one that prospective teachers developed metaphors in dictate writing. There are swimming in the ocean $(\mathrm{f}=1)$, eating vegetables $(\mathrm{f}=1)$, fear $(\mathrm{f}=1)$ and the darkness comes when the clouds cover the sun $(\mathrm{f}=1)$ metaphors.

Metaphor is an effective tool determining the feelings and ideas. In this research metaphors' benefits used for determining the perception on dictate writing of prospective music teachers and important information gathered. In the scope of this research both positive and negative perceptions of prospective teachers explained by different metaphors on dictate writing. It is fairly understandable that prospective music teachers love these studies, which they accepted its importance to become better music teachers, but comprehend that it also needs very much effort and sometimes they think that they dislike. When the results of the research evaluated, it is found important that the prospective teachers should be aware of studying dictate writing accompanying by educators is a requirement. To help to the prospective teachers during their conscious way of education experiences and to support when they are having difficulties are things educators shouldn't neglect. Besides, to the educators working on musical hearing field, it is recommended that different teaching methods and approaches to use, searching studying methods special for the field, reviewing the related literature, applying in the courses and updating course syllabuses in definite periods of time to motivate and increase the success of the prospective teachers to take attention to the course. 